\title{
Homologous Recombination Repair Gene
}

National Cancer Institute

\section{Source}

National Cancer Institute. Homologous Recombination Repair Gene. NCI Thesaurus.

Code C153246.

A gene involved in homologous recombination repair of DNA double-strand breaks. 